\title{
Effect of Waste Plastic Oil on Engine Performance and Durability
}

\author{
Khongdet Phasinam ${ }^{1}$, Thanwamas Kassanuk ${ }^{2}$ \\ ${ }^{1,2}$ School of Agricultural and Food Engineering, Faculty of Food and Agricultural Technology, Pibulsongkram Rajabhat \\ University, Thailand \\ 11phasinam@psru.ac.th, ${ }^{2}$ t.kassanuk@gmail.com, ${ }^{2}$ t.kassanuk@gmail.com
}

\begin{abstract}
Thailand has had the policies supporting the production and uses of renewable and alternative energies in order to reduce the imports of the fuels from other countries. Producing the fuels from plastic wastes can lower the pollution and energy problems in the country in order to ensure that the fuels can actually be the alternatives. The purpose of this research study is to compare the effects of using the diesel fuel from the plastic wastes on the single cylinder engines by comparing the performances and wears of the engines with the commercial diesel fuel and waste plastic oil. There were two tests: 1) the engine performance test and 2) the engine wear test. According to the results of the engine performance test, it was found that the waste plastic oil resulted in the torque and brake power lower than those of the commercial diesel fuel for about $3 \%$ at 2,200 revolutions per minute. However, the waste plastic oil had the lower fuel consumption rate than that of the commercial diesel fuel. As a result, the waste plastic oil had the specific fuel consumption that was lower than that of the commercial diesel fuel for about $2 \%$. Regarding the engine wears, it was found that the waste plastic oil caused slightly more wears than the commercial diesel fuel. It was concluded that the waste plastic oil was an alternative energy that had the potentials of the commercial diesel fuel without modifying the engines.
\end{abstract}

\section{Index Terms}

Waste Plastic Oil, Diesel Engine, Engine Performance, Wearing

Article Received: 10 August 2020, Revised: 25 October 2020, Accepted: 18 November 2020

\section{Introduction}

Thailand had to mainly rely on importing energies from other country. It was found that 60 percent of the demands for commercial energies were initially from the imports. According to the data in 2019, it was found that the percentage of the imported crude oil was high ( 87 percent) by comparing it to that of the local crude oil. It also tended to rise because the volume of the petroleum production could not meet the demands [1].

The serious developments of the renewable and alternative energies would reduce relying and importing the fuels. Therefore, the government had policies promoting the renewable and alternative energies produced in the country. The energies include wind power, solar energy, water power, biomass, wastes, biogases and bio fuels. The goals were to lower the percentages of the renewable and alternative energies in the forms of electric power, heat and bio fuels of the final uses of energies to 30 percent by 2037 [2]. Hence, driving the uses of the renewable and alternative energies is very important.

Moreover, the rapidly economic expansion changed the consumption behaviors of people in the country. Consequently, the problems about wastes occurred in the country. In 2018, there were 27.93 tons of wastes or 76,529 tons per day [3]. Most methods for disposing the wastes were not correct according to academic principles. This led to the problems affecting the environments and health of people [4]. However, these wastes could be energy sources [5]. Thus, adding values to the wastes in order to produce renewable energies such as electric power, heat or fuels was an alternative that did not only solve the environmental problems, but it would also overcome the country's energy crisis [6].

Plastic wastes contain hydro carbon compounds similar to fuels. Accordingly, the wastes can be processed back to fuels by reducing the sizes of molecules in order to produce liquid fuels. This must be done through pyrolysis or thermal treatment [7] that decomposes substances with high molecular masses with heat in oxygen-free conditions. The temperatures are about $450-600{ }^{\circ} \mathrm{C}$ [8]. These lead to three types of products: solids, liquids and gases [9]. The liquids obtained pyrolysis have the properties similar to that of diesel fuel [10].

According to the previous studies, the properties of the oil produced from the plastic wastes were tested with the engine. It was found that the waste plastic oil had the heating value, cetane number, specific gravity, viscosity and flash point slightly higher than that of the diesel fuel. By testing the oil with the engine; the power during the highest loads and specific fuel consumption were higher than 5 $8 \%$. The releases of nitrogen oxide and carbon dioxide were similar. The properties of the waste plastic oil were similar to that of the diesel fuel [11]-[13]. Nonetheless, although this oil could be a commercially renewable fuel, the qualities were diversely dependent on various factors such as technologies, production systems and raw materials. Thus, it was necessary to have supporting data about performances and engine wears in order to efficiently use the waste plastic oil and to perfectly replace the commercial diesel fuel without affecting engines.

\section{Research Objectives}

The purpose of this research study is to compare the effects of using the diesel fuel from the plastic wastes on the single cylinder engines by comparing the performances and wears of the engines with the commercial diesel fuel (CDF) and waste plastic oil (WPO). 


\section{Research Methods}

\section{A. Fuels}

The tested diesel fuel was commercial according to the standard of the Department of Energy Business [14]. By comparing it to the diesel fuel produced from $100 \%$ plastic wastes through pyrolysis from the waste plastic oil refinery of Suranaree University of Technology, the properties of most oil were consistent with the announcements of the department. This excepted the refinery values (Table I). The oil was classified as high speed diesel (HSD).

Table I The properties of the refined diesel oil compared to the properties of the diesel oil in the announcement of the

Department of Energy Business

\begin{tabular}{cccccc}
\hline \multirow{2}{*}{ Fuel Properties } & Test Method & WPO & \multicolumn{3}{c}{ Commercial Diesel Fuel } \\
\cline { 6 - 7 } & & & Limit & HSD & LSD \\
\hline Density at $15^{\circ} \mathrm{C}\left(\mathrm{kg} / \mathrm{m}^{3}\right)$ & ASTM D 1298 & 0.8111 & Min & 0.81 & - \\
Kinematic Viscosity at $40^{\circ} \mathrm{C}(\mathrm{cSt})$ & ASTM D 445 & 3.103 & Min & 1.8 & 0.92 \\
Cetane Number & ASTM D 613 & 60 & Min & 50 & - \\
Cetane Index & ASTM D 976 & 67 & Min & 50 & 45 \\
Flash Point $\left({ }^{\circ} \mathrm{C}\right)$ & ASTM D 93 & 50.5 & Min & 52 & 52 \\
Cloud Point $\left({ }^{\circ} \mathrm{C}\right)$ & ASTM D 97 & 15 & Min & 10 & 16 \\
Oxidation Stability $\left(\mathrm{g} / \mathrm{m}^{3}\right)$ & ASTM D 2274 & 17.8 & Max & 25 & - \\
Sulfur Content $(\% \mathrm{w} / \mathrm{w})$ & ASTM D 2622 & 0 & Max & 0.005 & 1.5 \\
Ash Content $(\% \mathrm{w} / \mathrm{w})$ & ASTM D 482 & 0.005 & Max & 0.01 & 0.02 \\
$90 \%(\mathrm{~V} / \mathrm{V})$ Distillation $\left({ }^{\circ} \mathrm{C}\right)$ & ASTM D 86 & 371.9 & Max & 357 & - \\
Polyaromatic Hydrocarbons $(\% \mathrm{w} / \mathrm{w})$ & ASTM D 2425 & 3.1 & Max & 11 & - \\
Water Content $(\% \mathrm{w} / \mathrm{w})$ & ASTM D 2709 & 0 & Max & 0.05 & 0.3 \\
Lubricity Corrected $(\mu \mathrm{m})$ & CEC F-06-96 & 350 & Max & 460 & - \\
\hline
\end{tabular}

\section{B. Experimental Setup}

The test diesel engine was a new single cylinder engine of HONMAR. Its model was DH850E. It was ready to use. The diesel engine performance and wear test kit was of ESSOM. Its model was MT502HD (Fig. 1). The technical data of the diesel engine are shown in Table II. The test kit and measuring tools for the engine performances and durability are presented in Fig. 2.

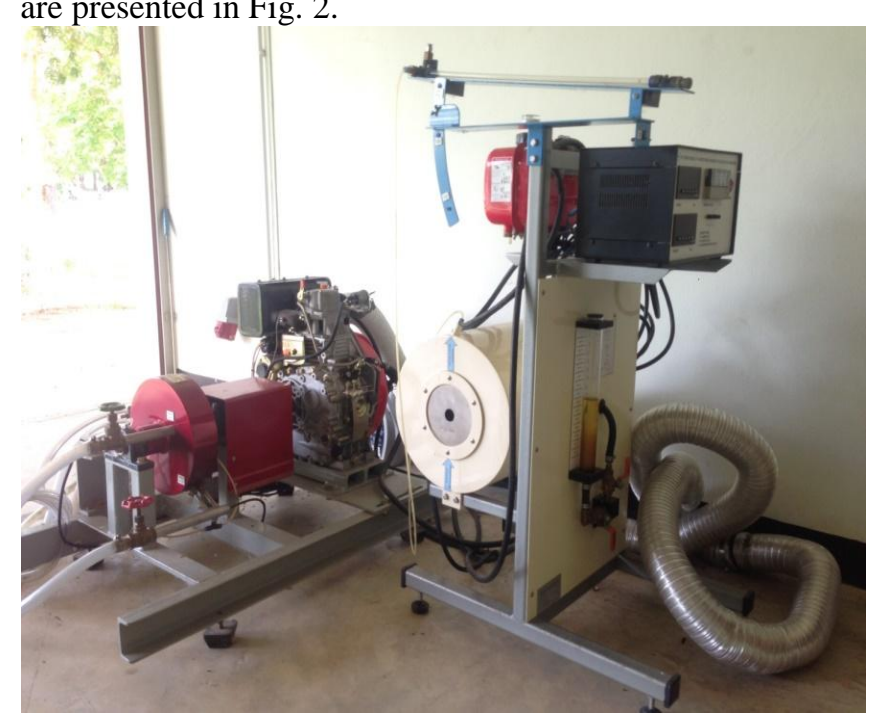

Fig. 1 Experimental setup for engine testing
Table II Test engine specifications

\begin{tabular}{lc}
\hline \multicolumn{1}{c}{ Specifications } & Honmar Model DH850E \\
\hline Horse Power (hp) & 6.7 at 3,600 rpm \\
Engine Type & Single-cylinder, 4-stroke \\
Cooling System & Air Cooled Type \\
Combustion System & Direct Injection \\
Cylinder Bore x Stroke (mm x mm) & $78 \times 62$ \\
Cylinder Volume ( $\left.\mathrm{cm}^{3}\right)$ & 296 \\
Engine Start System & Recoil \\
Fuel Capacity (liter) & 3.5 \\
Fuel Type & Diesel \\
Engine Oil Capacity (liter) & 1.1 \\
Engine Dimension (mm) & $427 \times 383 \times 450$ \\
\hline
\end{tabular}

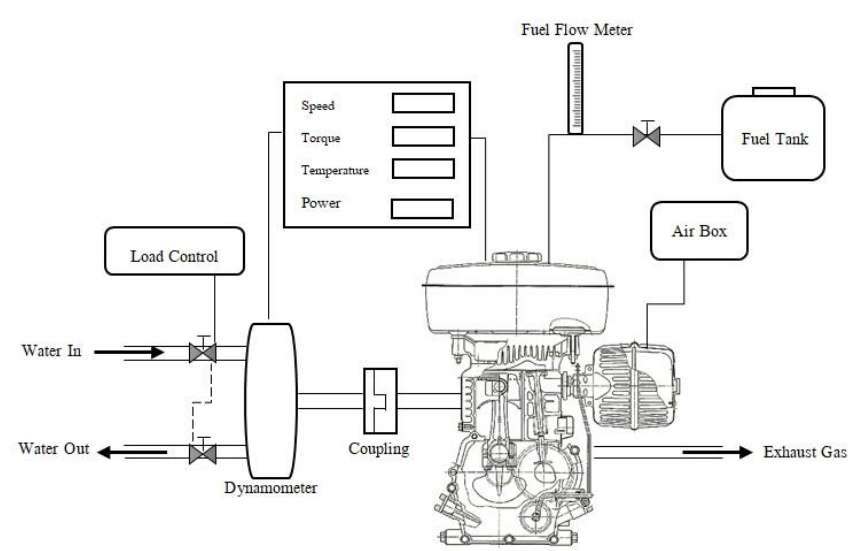

Fig. 2 Schematic diagram of the experimental installation

\section{Standards and Test}

The test was divided into two parts. The first part was the engine performance test according to the ISO 1550:2016 Internal Combustion Engine-Determination and Method for the Measurement of Engine Power-General Requirements, which was used as the reference for specifying the load of the engine during the engine durability test. The performances consisted of 1) engine break power, 2) engine break torque and 3) specific fuel consumption. The test started from warming the engine at 1,000 revolutions per minute $(\mathrm{rpm})$ until the operating engine temperature was stable at $70^{\circ} \mathrm{C}$, and the initial speed of the engine was set to $2,700 \mathrm{rpm}$. Then, the engine load was increased with the dynamometer until the speed of the engine was decreased. The value was recorded every $100 \mathrm{rpm}$ until the speed of the engine was reduced to $1,700 \mathrm{rpm}$. Then, the test was over. The data were presented and analyzed in the form of the engine performance graph according to the international standards. The second part of the test was the engine durability test referring to the 200-hr Screening Test for Alternative Fuels or EMA 200-hr Test [16], which was the durability test standard for engines using alternative or renewable energies. In the test, the load was specified as the duty cycle as shown in Table III. The test was repeated for 18 hours (six cycles) and stopped for six hours in order to ensure that the temperature of the engine was equal to the ambient temperature. The test was repeated until it was tested for 200 hours. The durability of the engine was evaluated by measuring the properties of the engine oil 
every 50 hours. The examined properties including viscosity, density, alkalinity and contaminated water quantity in order to study the effects of the waste plastic oil on the lubrication system of the engine and to measure the wears of other components of the engine. The metal and non-metal contaminants such as iron $(\mathrm{Fe})$, aluminium $(\mathrm{Al})$, copper $(\mathrm{Cu})$ and chromium $(\mathrm{Cr})$ were identified in order to find the wears of the other components after using the waste plastic oil because the different components were made of the different materials. Therefore, the contaminants found in the engine oil could be used as the guidelines for identifying the wears of the components.

Table III The cycle of the EMA 200-hours durability test

\begin{tabular}{ccccc}
\hline Cycle Step & Engine Speed (rpm) & Torque & Power & Time (min) \\
\hline 1 & Rated & - & Rated & 60 \\
2 & $85 \%$ & Maximum & $95 \%$ & 60 \\
3 & $90 \%$ & $28 \%$ & $25 \%$ & 30 \\
4 & Idle & 0 & 0 & 30 \\
\hline
\end{tabular}

\section{Results}

\section{A. Performance Test}

According to the results of the engine break torque test, it was found that the torque of the WPO was slightly lower that of the CDF (Fig. 3). Especially for the speeds of 2,000 $2,600 \mathrm{rpm}$ that were the normal speeds of the engine, the highest torque of the engine was 2,200 rpm. The WPO had the highest torque of $11.0 \mathrm{~N}-\mathrm{m}$, while that of the CDF was 12.2 N-m. That is, the torque of the WPO was lower than that of the CDF for about $3 \%$.

By calculating the engine brake power, it was found that the brake power tended to increase according to the speed. Additionally, both types of the diesel fuel had the similar results (Fig. 4). The highest power of the engine was at the speed of 2,500 rpm. The CDF had the highest power of 2.93 $\mathrm{kW}$, while the CDF had the highest power of $2.83 \mathrm{~kW}$. However, the power from the WPO was averagely lower than that of the CDF for $7 \%$ at the speeds of $1,700-2,300$ rpm.

Regarding the specific fuel consumption (SFC), it was found that the engine using the WPO had the lowest average SFC of $0.44 \mathrm{~g} / \mathrm{kW}-\mathrm{hr}$. Similarly, the CDF had the average SFC of $0.41 \mathrm{~g} / \mathrm{kW}-\mathrm{hr}$. The average SFCs were calculated at the speeds of 2,000 - 2,600 rpm as shown in Fig. 5.

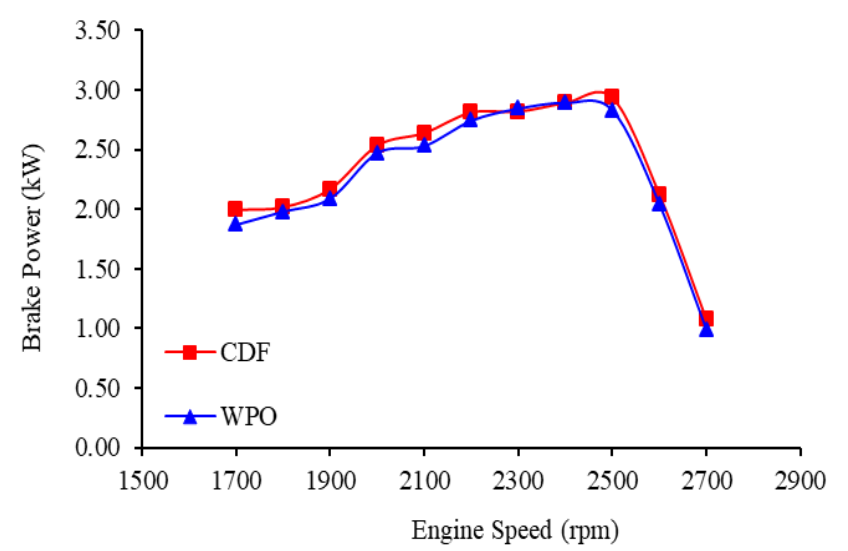

Fig. 3 The engine speed per brake power of the CDF and WPO

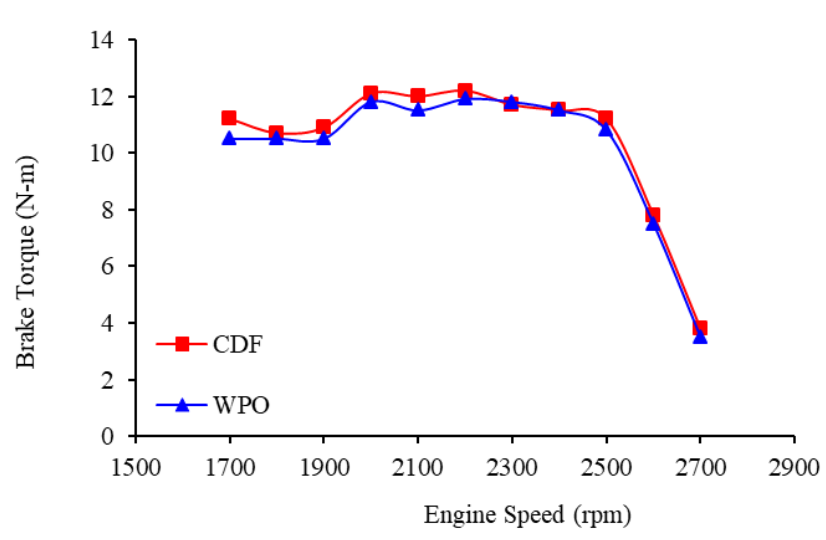

Fig. 4 The engine speed per brake torque of the CDF and WPO

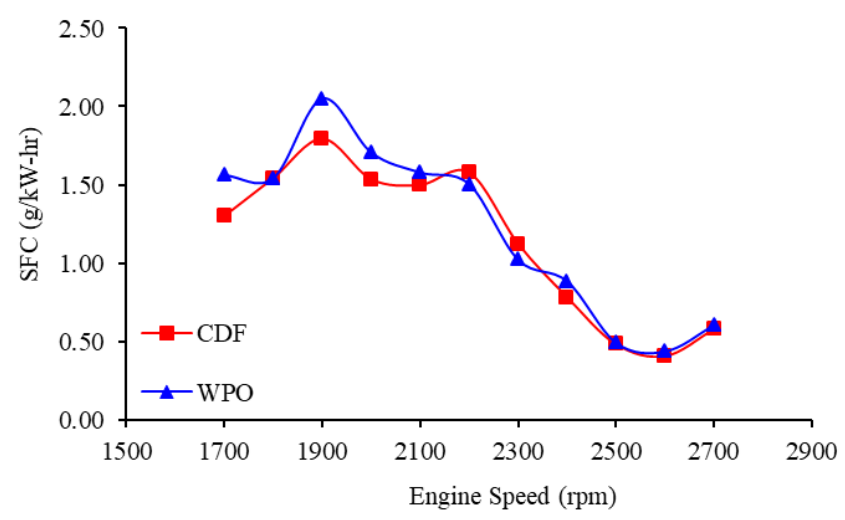

Fig. 5 The engine speed per specific fuel consumption of the CDF and WPO

\section{B. Durability Test}

The properties of the engine oil during the durability test of the CDF and the WPO were shown in Table IV and Table $\mathrm{V}$, respectively. The properties of the engine oil were changed according to the time. The viscosity and density tended to increase, while the alkalinity was decreased. By analyzing the metal and non-metal contaminants; it was found that the amounts of $\mathrm{Fe}, \mathrm{Pb}, \mathrm{Cr}, \mathrm{Cu}, \mathrm{Al}$ and $\mathrm{Si}$ increased during the test.

Table IV The properties of the engine oil during the durability test of the commercial diesel fuel

\begin{tabular}{lcccc}
\hline \multirow{2}{*}{ Properties } & \multicolumn{4}{c}{ Operating Hours (hr) } \\
\cline { 2 - 5 } & $\mathbf{5 0}$ & $\mathbf{1 0 0}$ & $\mathbf{1 5 0}$ & $\mathbf{2 0 0}$ \\
\hline Viscosity at $100{ }^{\circ} \mathrm{C}(\mathrm{cSt})$ & 15.00 & 16.20 & 17.40 & 17.70 \\
Density at $100{ }^{\circ} \mathrm{C}\left(\mathrm{kg} / \mathrm{m}^{3}\right)$ & 851.60 & 853.00 & 854.50 & 856.00 \\
Alkalinity $(\mathrm{gKOH} / \mathrm{g})$ & 10.80 & 10.20 & 10.50 & 9.80 \\
$\mathrm{Fe}(\mathrm{ppm})$ & 22.33 & 23.10 & 25.33 & 25.68 \\
$\mathrm{~Pb}(\mathrm{ppm})$ & 1.44 & 2.64 & 9.12 & 15.84 \\
$\mathrm{Cr}(\mathrm{ppm})$ & 0.90 & 1.60 & 2.60 & 3.90 \\
$\mathrm{Cu}(\mathrm{ppm})$ & 0.93 & 1.74 & 3.45 & 4.20 \\
$\mathrm{Al}(\mathrm{ppm})$ & 4.25 & 5.60 & 8.25 & 14.90 \\
$\mathrm{Si}(\mathrm{ppm})$ & 4.65 & 4.86 & 6.38 & 7.53 \\
\hline
\end{tabular}


Table $\mathbf{V}$ The properties of the engine oil during the durability test of the waste plastic oil

\begin{tabular}{lcccc}
\hline \multirow{2}{*}{ Properties } & \multicolumn{4}{c}{ Operating Hours (hr) } \\
\cline { 2 - 5 } & $\mathbf{5 0}$ & $\mathbf{1 0 0}$ & $\mathbf{1 5 0}$ & $\mathbf{2 0 0}$ \\
\hline Viscosity at $100{ }^{\circ} \mathrm{C}(\mathrm{cSt})$ & 15.10 & 15.71 & 16.32 & 16.91 \\
Density at $100{ }^{\circ} \mathrm{C}\left(\mathrm{kg} / \mathrm{m}^{3}\right)$ & 852.50 & 853.00 & 853.50 & 854.00 \\
Alkalinity $(\mathrm{gKOH} / \mathrm{g})$ & 11.00 & 10.20 & 9.50 & 8.50 \\
$\mathrm{Fe}(\mathrm{ppm})$ & 23.22 & 24.07 & 26.50 & 26.95 \\
$\mathrm{~Pb}(\mathrm{ppm})$ & 4.32 & 6.00 & 7.56 & 10.44 \\
$\mathrm{Cr}(\mathrm{ppm})$ & 0.85 & 1.60 & 2.65 & 3.45 \\
$\mathrm{Cu}(\mathrm{ppm})$ & 0.93 & 1.50 & 2.52 & 3.81 \\
$\mathrm{Al}(\mathrm{ppm})$ & 3.65 & 5.50 & 6.60 & 7.55 \\
$\mathrm{Si}(\mathrm{ppm})$ & 5.80 & 6.13 & 6.97 & 8.86 \\
\hline
\end{tabular}

\section{Discussions}

In this study, the performance and durability of the single cylinder diesel engine using the commercial diesel fuel and the waste plastic oil were identified. By testing the performance of the engine at the different speeds, it was found that the graphs of the brake torque, brake power and specific fuel consumption changed in the same directions. The torque and brake power of the engine using the waste plastic oil were lower than that of the commercial diesel fuel. Nevertheless, the specific fuel consumptions of the waste plastic oil and the commercial diesel fuel were very similar. By testing the durability of the engine, it was found that the viscosity and density were increased. The alkalinity was decreased. The metal and non-metal contaminants were increased during the test. The engine consisted of many components including static components and dynamic components. Generally the dynamic components were made of metals that had frictions on the static components. The mentioned movements resulted in wears. Hence, the engine must have the lubricant that did not only lubricate the components, but it also cleaned the metal components. Normally, lubricants have reactions with oxygen in the air. Then, it results in acidic substances and gum. These reactions occur at high temperatures that degrade the lubricants with increased acidity and viscosity. If the acidity of lubricants is increased, then the metal components of machines were eroded [17]. It is found that Fe has the highest amount since $\mathrm{Fe}$ is a main component of the parts of engines. In overall, the commercial diesel oil had the amount of Fe slightly lower than that of the other oil. Possibly, it was because the commercial diesel fuel had additives such as biodiesel in order to improve the lubrication. Thus, the test results could confirm that the waste plastic oil had the potentials for being used in engines and its qualities could be improved and equivalent to that of the commercial diesel fuel.

\section{Recommendations}

\section{A. Recommendations for Practices}

Since the properties and test results of the waste plastic oil were similar to that of the commercial diesel fuel, we can use the waste plastic oil without modifying engines. For modified engines with adjusted fuel injection angles and other modifications, the waste plastic oil may improve the performance of the engines and completely replace the commercial diesel fuel.

\section{B. Recommendations for Further Research}

1. Further studies should be conducted, or the qualities of the oil should be improved in order to be equivalent to that of the commercial diesel fuel.

2. Further studies about the pollution caused by engines should be conducted.

3. Field studies about the wears of engines should be conducted.

\section{Conclusion}

This study presented the effects of the waste plastic oil on the diesel engine. By comparing the performance and wears of the engine using the waste plastic oil and the commercial diesel fuel, it was found that the performance was slightly affected since the brake power was decreased for about $6 \%$. The specific fuel consumptions of the waste plastic oil and the commercial diesel fuel were very similar. Therefore, the break thermal efficiency of the engine using the waste plastic oil was lower than that of the commercial diesel fuel for only $1.6-3.0 \%$. For the wears of the engine, it was found that the waste plastic oil insignificantly resulted in more wears than the commercial diesel fuel.

\section{Acknowledgement}

This is grateful for to Pibulsongkram Rajabhat University for the research fund number RDI-2-60-2-42 and refinery of Center of Excellence in Biomass, Suranaree University of Technology for providing the waste plastic oil for this study.

\section{References}

[1] Department of Mineral Fuels. (2019). Energy for All. [Online]. Available: https://dmf.go.th/public/list/data/index/me nu/668

[2] Department of Alternative Energy Development and Efficiency. (2020, Oct.). Alternative Energy Development Plan: AEDP 2018. [Online]. Available: https://www.dede.go.th/ewt_dl_link.php?n id $=54495$

[3] Pollution Control Department. (2018, Jul.). The Reports about the Community Waste Disposal Sites in Thailand in 2018. [Online]. Available: http://infofile.pcd.go.th/Waste/Wst2018.pd f 
[4] M. Syamsiro, H. Saptoadi, T. Norsujianto, P. Noviasri, S. Cheng, Z. Alimuddin, and K. Yoshikawa, "Fuel Oil Production from Municipal Plastic Wastes in Sequential Pyrolysis and Catalytic Reforming Reactors," Energy Procedia, vol. 47, pp. $180-188,2014$.

[5] S. Kommana, P. G. Chowdary, and A. H. R. Madhuri, "Optimization of Injection Pressure and Compression Ratio of VCR CI Engine Fueled with Waste Plastic Oil Blended with Diesel," International Journal of Mechanical and Production Engineering Research and Development, vol. 10, pp. 2585 - 2600, 2020.

[6] National Assembly Library of Thailand. (2016, Oct.). The Fuel from the Plastic Wastes. [Online]. Available: https://library2.parliament.go.th/ejournal/c ontent_af/2559/oct2559-1.pdf

[7] J. Walendziewski, "Engine Fuel Derived from Waste Plastics by Thermal Treatment," Fuel, vol. 81, pp. 473-481, 2002.

[8] B. V. Beld, E. Holle, and J. Florijn, "The Use of Pyrolysis Oil and Pyrolysis Oil Derived Fuels in Diesel Engines for CHP Applications," Applied Energy, vol. 102, pp. 190 - 197, 2013.

[9] J. senabut, A. Pinchaimoon, and K. Srithiang, "The Improvement in Quality of Fuel Oil by Pyrolysis of Polypropylene Using of an amorphous Silica Catalyst Made," Industrial Technology Lampang Rajabhat University Journal, vol. 10, pp. $12-23,2017$.

[10] M. Banar, A. Akyıldız, A. Özkan, Z. Çokaygil, and Ö. Onay, "Characterization of Pyrolytic Oil Obtained from Pyrolysis of TDF (Tire Derived Fuel)," Energy Conversion and Management, vol. 62, pp. $22-30,2012$.

[11] K. Wattanavichien and A. Kannika, "Synthetic Diesel Fuel from Waste Plastic: Conversion and the Use in a Diesel Engine," in Pro. ME-NETT, 2019, pp. 155 -168 .
[12] R. K. Gopidesi, G. R. Sankar, A. D. P. Kumar, A. S. Kumar, and B. Srimal, "Evaluating the Performance and Emission Characteristics of CI Engine with Waste Plastic Oil," International Journal of Mechanical and Production Engineering Research and Development, vol. 9, pp. 1015 - 1020, 2019.

[13] G. S. Jatadhara, T. K. Chandrashekar, and N. K. Kumar, "Experimental Study on Characteristics of Direct Injection Compressed Ignition Engine using Waste Plastic Oil and Biodiesel Blends," International Journal of Mechanical and Production Engineering Research and Development, vol. 10, pp. 2085 - 2094, 2020.

[14] Department of Energy Business. (2020, Jun.). Notification of the Department of Energy Business Re: Specification for Appearance and Quality of Diesel Oils. [Online]. Available: http://elaw.doeb.go.th/document_doeb/TH/ 699TH_0001.pdf

[15] International Organization for Standardization. (2016, Dec.). ISO 15550:2016 Internal Combustion Engines - Determination and Method for the Measurement of Engine Power - General Requirements. [Online]. Available: https://www.iso.org/standard/70030.html

[16] Department of Energy. (1982). EMA 200 Hour Test Hydrogenated Soy Ethyl Ester and Diesel Fuel. University of Idaho, Department of Agricultural Engineering, USA.

[17] P. Kamthita and T. Limlertchareonwanit, "Acetic Acid Treatment of Used Lubricating Oil with Heavy Metals Adsorption by Activated Carbon from Water Hyacinth," Thai Science and Technology Journal, vol. 27, pp. 56-67, 2018. 